\title{
Food or fuel: what does India want to secure?
}

\section{Introduction}

On September 25th 2015, countries adopted a set of seventeen goals to ensure prosperity for all as part of a new sustainable development, commonly known as SDG, over the next fifteen years. The second goal in the list is: Zero Hunger. This is not an easy target to achieve. A radical change of the agriculture system is needed to nourish today's 795 million hungry and the additional 2 billion people expected by $2050 .{ }^{1}$ India is no different. For India the challenge is its increasing population, limited land, degrading land and changing land use. Climate change is putting more pressure on the resources, impacts of climate change is visible; the majority of the agrarian community of the country, can no longer make ends meet on their land and are forced to migrate to cities in search of better opportunities. Renewable energy resources like solar and biomass have solution to many climate change issues; however they too call for critical and detailed analysis before policies are rolled out.

\section{India's Bio fuel policy}

Under the aegis of Ministry of New and Renewable Energy, Government of India, National Bio-fuel policy was formulated in year 2008. The idea was to create conducive environment to bring in more biofuels in the market to replace fossil fuel. The document had a roadmap to achieve $20 \%$ of transport fuel requirement from biomass by year 2017. Bio fuel policy, 2008, of India also says, "The Indian approach to bio fuels, in particular, is somewhat different to the current international approaches which could lead to conflict with food security. ${ }^{2}$ It is based solely on non-food feedstock's to be raised on degraded or wastelands that are not suited to agriculture, thus avoiding a possible conflict of fuel vs. food security". By and large, Biofuel policy is welcome change.

\section{Ethanol as Biofuel}

Bio fuel policy talked about producing ethanol from molasses, a by-product from sugar industry. India is the world second largest producer of sugarcane after Brazil (Figure 1).

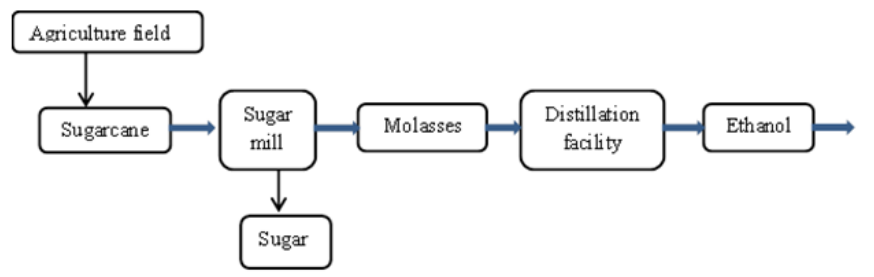

Figure I Process diagram for sugar to ethanol production.

Figure 1 shows the process flow diagram for Sugarcane to ethanol production route. As on date, 2229Million litres of molasses were available in the Indian market. ${ }^{3}$ This had a capacity to produce around 550Millionlitres of ethanol which could meet around 8-10\% of transport fuel requirement. Ethanol has an established market in the country as shown in Figure 2. However the share of ethanol available in the market for fuel blending has increased to $23 \%$ in recent years. This certainly is a positive development post bio fuel policy came into action (Figure 2).
Volume 7 Issue 4 - 2017

Priyanka Kaushal

Department of Energy and Environment, TERI University, India

Correspondence: Priyanka Kaushal, Department of Energy and Environment, TERI University, 10 Institutional area, Vasant Kunj, New Delhi, India,

Email priyanka.kaushal@teriuniversity.ac.in

Received: January 31, 2017 | Published: September 12, 2017

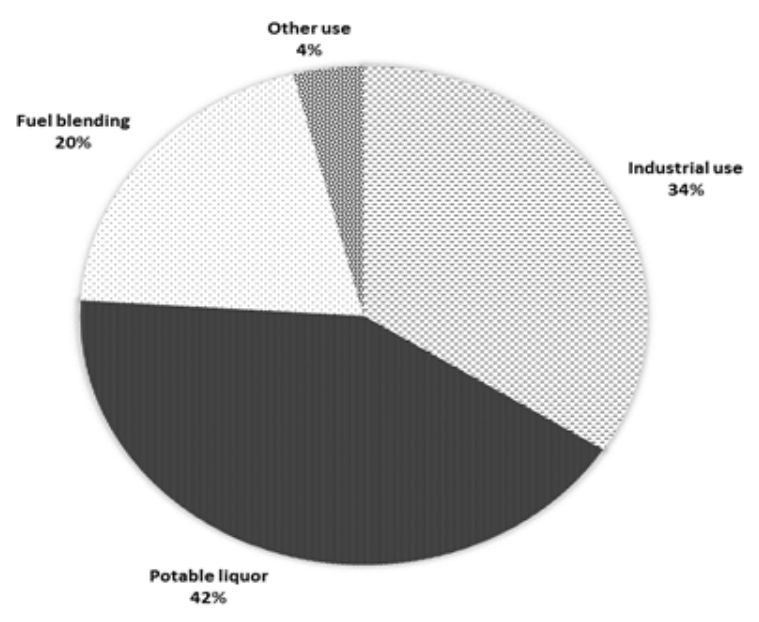

Figure 2 Bio ethanol market in India. ${ }^{4}$

\section{Concern in Biofuel policy}

This policy talked about cultivation on a degraded land. The whole purpose to resolve the food vs fuel conflict is defeated, if not upfront certainly subtly, when India talks of growing non-food feedstock on a degraded land. The point is: if one can grow or cultivate a crop on a degraded land, it is still a production from the land, irrespective of whether the yield is food or for fuel. India is a struggling country. It is struggling to secure energy, struggling to secure food and struggling to reduce emission, struggling to maintain its economic growth rate etc. India's population is around 1.2billion today which is growing at the rate of $1.19 \%$ annually. ${ }^{5}$ As on date, India holds $17 \%$ of global human population and $21 \%$ of global cattle population. However, India holds only about $2.5 \%$ of global land area. ${ }^{6}$ Other realities are the following: In less than 15years' time India will have to feed additional 210 million heads i.e. more than twice the German population today. ${ }^{7}$ India cannot afford to cut a minuscule of forest to bring in more land for agriculture, study suggest that for India's environmental and ecological balance around $35 \%$ of its land should be under forest/tree cover, however in reality it is around $22-24 \% .8$ 
Therefore the challenge here is to ensure affordable food for all its citizens without disturbing the ecological balance.

\section{Discussion}

Globally the land use has reached a tipping point. Around threequarters of the global land are under use for crops, livestock grazing and wood harvests. The remaining quarter gives services like clean water, biodiversity, stores carbon in trees etc. to support life on this planet. ${ }^{9}$ Earth Overshoot Day (EOD) is the date on which humanity's resource consumption for the year exceeds Earth's capacity to regenerate those resources that year, ${ }^{10}$ (Table 1) chronicles the EOD for last ten years. What is alarming is that the Earth Overshoot Day is arriving earlier with each passing year. Last year, 2016, the world as a whole needed 1.6 earths to meet its requirement in a sustainable manner. It also means that we are over exploiting our planet. The problem will become more acute with rising population. Food security is a challenge, this is the reason "Zero Hunger" is one of the top goals of SDGs (Sustainable Development Goals), spearheaded by UN. Climate change has made the issue of food security more vulnerable. Climate change increases the frequency and intensity of some disasters such as droughts, floods and storms. This has an adverse impact on livelihoods and food security. Climate-related disasters have the potential to destroy crops. Hence there is a need to develop crop (seed) that are resistant to climate change. Biotechnology has to take the centre stage to develop climate resistant crop, reclaim degraded land for farming etc.

Table I Chronicles of the EOD

\begin{tabular}{ll}
\hline Year & Earth overshoot day \\
\hline 2007 & $26-$ Oct \\
2008 & $23-$ Sep \\
2009 & $25-$ Sep \\
2010 & 21 -Aug \\
2011 & $27-$ Aug \\
2012 & 22 -Aug \\
2013 & 20 -Aug \\
2014 & $19-$ Aug \\
2015 & $13-$ Aug \\
2016 & 8-Aug \\
\hline
\end{tabular}

\section{Conclusion}

Sustainable development is the confluence of economicdevelopment, environment and society. Therefore our action should bring in the positive change for the society and should ensure the protection of natural resources benefiting local and ultimately global ecosystem. Land is one of the most priceless commodities. Hence any action that can induce land use change has to be evaluated and scrutinized exhaustibly not just for short term benefit but also for long term impacts.

\section{Acknowledgements}

None.

\section{Conflict of interest}

The author declares no conflict of interest.

\section{References}

1. Goal 2: End hunger, achieve food security and improved nutrition and promote sustainable agriculture; 2017.

2. MNRE. National Policy on Biofuel. India; 2008. p. 1-18.

3. ISMA. Hand book of Sugar statistics. India: Indian Sugar Mills Association; 2008.

4. Allan Mustard, Amit Aradhey. GAIN Indian biofuels annual report. USDA foreign agricultural service, Global Agriculture Information Network, India; 2012. p. 1-18.

5. Tradingeconomics. India population data, India; 2017.

6. FAO. Country resource profile, USA; 2006.

7. Population pyramid. Population Pyramids of the World from 1950 to 2100; 2017.

8. BB Tandon, PK Vasudeva. Inclusive Growth and Sustainable Development: Ideal for Indian Economy. India; 2010.

9. Tim Searchinger. Why Dedicating Land to Bioenergy Won't Curb Climate Change. India: WRI; 2015.

10. Nicolas Hulot. Earth Overshoot Day 2017 fell on August 2, Europe; 2017. 